\title{
ENSINO DE GRAMÁTICA NA CONTEMPORANEIDADE
}

\author{
TEACHING GRAMMAR TODAY
}

Lorenzo Vitral | Lattes | lvitral@gold.com.br Universidade Federal de Minas Gerais

\begin{abstract}
Resumo: O artigo visa a apresentar, em linhas gerais, o que é realizado na seção 3, as principais propostas de descrição gramatical desenvolvidas num manual de nossa autoria, nomeado "Gramática Inteligente do Português do Brasil" (VITRAL, 2017). As justificativas que embasam nosso manual são discutidas na seção 2 , na qual se elabora um breve histórico do debate sobre o ensino de língua portuguesa no Brasil.
\end{abstract}

Palavras-chave: Ensino de gramática; Português do Brasil; Gramática tradicional.

\begin{abstract}
The goal of this paper is to expose the main proposals of grammatical description developed in a book written by me, "Gramática Inteligente do Português do Brasil" (VITRAL, 2017). The justifications of our proposals are discussed in section 2, where we elaborated a short history about the discussion concerning Portuguese learning in Brazil.
\end{abstract}

Keywords: Grammatical learning; Brazilian Portuguese; Traditional Grammar.

\section{1 introdução ${ }^{1}$}

Como é amplamente conhecido, o ensino de língua portuguesa no Brasil como língua materna nas escolas públicas e privadas passou a sofrer questionamento amplo e consistente a partir, pelo menos, dos anos 70 do século passado.

O debate dessas últimas décadas acerca do tema levou boa parte dos nossos profissionais das áreas de letras e linguística, principalmente aqueles que têm "um pé" na Universidade, a se convencer do caráter supérfluo ou obsoleto do ensino da língua materna baseado na gramática nos moldes tradicionais. Neste ensino, como é também notório, tomado de forma genérica, a partir, portanto, de suas características centrais, sobretudo no período precedente ao que apontamos, as atividades pedagógicas são de dois tipos: estudos de estilos literários e leituras das obras relevantes; e, o que nos interessa mais de perto, memorização e aplicação de nomenclatura gramatical, colhida de manuais tradi-

\footnotetext{
1 Agradeço às sugestões de dois pareceristas anônimos. Erros eventuais são de minha responsabilidade.
} 
cionais e exemplificada também, basicamente, por textos do gênero literário.

A minha intenção neste texto é trazer, de início, um breve histórico do percurso da reflexão crítica acerca do ensino nos moldes tradicionais e, após isso, expor as linhas gerais do conteúdo de um manual de ensino de gramática, de minha autoria, intitulado “Gramática Inteligente do Português do Brasil” (VITRAL, 2017), que, a partir do estado da arte da crítica aos manuais tradicionais e com a inclusão de algumas conquistas inequívocas de teorias linguísticas contemporâneas, almeja poder desempenhar tanto papel instrumental na formação do professor de língua portuguesa quanto se constituir como um livro de consulta acerca de temas de língua e de gramática portuguesa para, sobretudo, alunos de ensino médio.

\section{Breve histórico do debate sobre o ensino de língua portuguesa no brasil}

A crença da necessidade de superar o ensino de língua portuguesa nos moldes tradicionais foi fundamentada, com muita propriedade, por inúmeros trabalhos ao longo das últimas décadas, dos quais se podem extrair os temas seguintes, que são bastante conhecidos:

(1) Necessidade de elaboração de uma gramática padrão da língua portuguesa.

(2) Insuficiência dos critérios de análise linguística empregados pelos manuais tradicionais.

(3) Revalorização de dialetos não contemplados pelos manuais tradicionais.

(4) Mudança de perspectiva em relação à unidade linguística central no ensino, que passa a ser o texto, e não mais a oração ou o período.

(5) O advento das novas tecnologias, como a internet e o celular, as quais dão início a uma transformação de nossa subjetividade, com consequências ainda não inteiramente descritas e compreendidas em vários campos da ordem do humano, fazendo-nos rever concepções sobre língua e ensino.

Em relação ao primeiro tema acima, um dos trabalhos de grande destaque é o de Hauy (1985). A autora, que ressalta, de início, ser o empenho crítico em relação aos manuais tradicionais proveniente, muitas vezes, dos próprios gramáticos tradicionais, demonstra, com farta exemplificação, e agora cito a autora, "[...] o estado caótico em que se encontram nossas gramáticas normativas." (HAUY, 1985, p. 5). Os aspectos principais de sua argumentação são os seguintes: 
(a) nenhuma das definições de oração - central, obviamente, na análise sintática - utilizada nos manuais tradicionais é inteiramente adequada;

(b) a exemplificação empregada nesses manuais é "muitas vezes errada e isso, em parte, devido às definições que as precedem” (HAUY, 1985, p. 26);

(c) há muitas divergências e contradições entre gramáticas e mesmo entre duas obras ou duas passagens numa mesma obra de um único autor; e, por fim,

(d) diversidade de conceituação e multiplicidade de análise de fatos sintáticos, o que se deixa refletir na nomenclatura exuberante e complexa, inadequada se levarmos em conta que se trata de manuais de ensino.

Ainda quanto ao primeiro tema, a autora mostra que há, pelo menos, quatro definições de oração utilizadas pelos vários autores dos manuais tradicionais: (1) a oração é uma expressão de um juízo; (2) a oração é a expressão de um pensamento; (3) a oração é um conjunto de palavras com sentido completo; e (4) a oração é uma frase com estrutura dual sujeito-predicado. Todas elas são insuficientes, ou seja, não abrigam todos os fatos, $\mathrm{o}$ que se deve, em parte, ao caráter não explícito das definições propostas. A melhor delas, e mais objetiva, é a que propõe a oração como um constituinte com sujeito e predicado, mas também esta definição, que, aliás, é clássica, traz suas dificuldades, já que há estruturas com sujeito e predicado que não chamadas de orações e há orações com os denominados verbos impessoais, como chover, haver, etc., em que parece haver predicado, mas não sujeito. Os autores tradicionais que perceberam o problema se conformaram com a suposta existência de orações com predicado, mas sem sujeito. Ora, esse "remendo" equivale a jogar fora a noção de predicação, levando-se em conta o que já explicitou Frege, ou seja, o predicado, tratado como uma função, é um termo aberto ou insaturado que necessariamente requer um argumento que o feche ou o sature (FREGE, 2009, p. 48).

No que concerne ao segundo e terceiro temas acima, são abundantes os exemplos, coletados de vários manuais tradicionais, que mostram haver uso de exemplificação inadequada bem como de divergências e contradições entre os gramáticos e mesmo entre duas obras ou duas passagens numa mesma obra de um único autor. Vou ilustrar esse amplo trabalho de coleta de evidências feito por Hauy com dois exemplos.

No primeiro deles, trata-se de determinar o estatuto categorial/funcional da palavra "como" em orações do tipo de:

(1) Alguns o consideram como herói.

Vejamos como os gramáticos definem esta palavra: 
Nascentes (1959): conjunção

Cunha (1980): conectivo

Rocha Lima (1979): palavra

Luft (1971): preposição

Oliveira (1960): preposição.

Embora, é claro, haja muito mais concordância do que divergência entre os gramáticos tradicionais, fatos como o que acabamos de ver não são tão limitados como se poderia imaginar à primeira vista e colaboraram para a eliminação da visão idealizada da gramática tradicional como uma doutrina inteiramente coesa e homogênea. As consequências negativas desse tipo de constatação para o ensino, sobretudo nas séries escolares iniciais, são facilmente imagináveis e deixo-as a cargo do leitor.

Em relação ao quarto tópico proposto logo acima, a autora discute o exemplo da análise dos manuais para construções em que ocorre um verbo causativo como "deixar" em volteios como "Deixaram sair as pessoas da sala". Ela nos mostra que há cinco análises diferentes para esse tipo de construção, que divergem em relação à existência de locução verbal, de oração objetiva direta, de predicativo do objeto, de dois objetos ou do estatuto duplo de sujeito e objeto do sintagma que aparece após o verbo. Em seguida, ela distribui os vários gramáticos em grupos de acordo com a análise adotada.

O que foi comentado é suficiente para se ter uma ideia da direção do trabalho de Hauy e concordar com sua conclusão de que, mesmo considerando legítimo o ensino de gramática no contexto do ensino de $\mathrm{PB}$ como língua materna, é preciso elaborar um texto gramatical padrão que elimine as dificuldades apontadas. Uma de suas sugestões é procedermos a uma triagem dos conteúdos de gramática a serem abordados neste eventual texto e, ao fazê-lo, agirmos com parcimônia no que se refere ao emprego da nomenclatura gramatical, que, como também é sabido, é exuberante e não consegue descrever os fatos gramaticais de maneira objetiva; por isso, é bastante inadequada também do ponto de vista do ensino.

Passemos agora a comentar o segundo tema da crítica contemporânea do ensino tradicional, isto é, (2) insuficiência dos critérios de análise linguística empregados pelos manuais tradicionais.

Como é igualmente conhecido, concomitantemente a essa crítica, que chamarei de interna, dos manuais tradicionais, representada aqui pelo trabalho de Hauy, houve uma crítica à perspectiva tradicional que chamarei de externa, já que fundamentada por meio de conquistas teóricas desenvolvidas pela linguística do século XX, o que permitiu 
a elaboração de uma crítica severa aos critérios de análise da Gramática Tradicional, cuja inestimável contribuição foi dimensionada na história, como patrimônio do nosso saber.

O que chamei de crítica externa pode ser ilustrada pelos trabalhos de Perini (1985) e Ilari (1985) e de muitos outros autores. Uma das consequências desses trabalhos é o de lançar dúvidas a respeito da viabilidade do ensino de gramática baseada na perspectiva tradicional, mesmo de posse de uma eventual gramática padrão, como proposto por Hauy.

Um dos aspectos mais salientes dessa crítica aos pressupostos teóricos tradicionais é a constatação do emprego indistinto e assimétrico dos critérios formal e semântico na descrição e análise de fatos da língua, o que pode ser ilustrado com a insuficiência do uso do papel temático agente - critério semântico, portanto - para identificação do sintagma que desempenha a função de sujeito. Embora, é claro, os gramáticos não sejam ingênuos a ponto de admitirem que bastaria levar em conta esse conteúdo para encontrarmos o sujeito da oração, na prática de análise sintática, é fomentada a crença errônea da suficiência ou quase suficiência desse recurso. Essa crítica levou-nos a concluir que a gramática tradicional muitas vezes cria sua nomenclatura ou descreve um fenômeno ora baseada em critério semântico ora em critério formal, o que gera assimetrias teóricas que desfavorecem a apreensão dos pontos de gramática de uma maneira reflexiva e mais transparente.

O terceiro ponto que destacamos no início, ou seja, (3) revalorização de dialetos não contemplados pelos manuais tradicionais, é hoje uma conquista da mentalidade brasileira no que se refere ao ensino de língua materna. Colaboraram para isto o campo fértil encontrado pela sociolinguística laboviana nas universidades brasileiras, que ajudou a relativizar o valor da norma culta entre nós (CASTILHO, 1990), e também mudanças socioeconômicas no Brasil a partir da década de 60, ou seja, a crescente urbanização e transferência para as cidades de grandes contingentes da população rural, o que provocou a inclusão na escola de segmentos sociais que, até então, tinham se mantido à margem da escolarização. Essas classes não dispunham dos meios de acesso à língua veiculada pela tradição, que, como é notório, é aquela de nossos melhores escritores.

Hoje em dia, por outro lado, é bem provável que diferenças dialetais salientes sejam colhidas, com mais transparência, no contraste entre falares de favelas ou comunidades pobres e da classe média com mais escolaridade.

A partir, portanto, da década de 70, surge um número considerável de trabalhos que contribuíram na direção apontada, sendo possível destacar o trabalho pioneiro de Lemle e Naro (1977), que defenderam o estatuto de regra variável no que se refere à aplicação da regra de concordância verbal, ou seja, mostraram que a concordância pode ser realizada 
ou não pelo falante em razão de diversos fatores de natureza linguística e extralinguística. $\mathrm{Na}$ descrição deste fenômeno, é destacado certo número de fatores condicionadores que favorecem ou desfavorecem a realização da concordância verbal. Como é sabido, existem os fatores extralinguísticos como faixa etária, escolaridade, localização da comunidade de fala, gênero dos falantes, etc., e os fatores linguísticos ou internos. Em relação ao fenômeno da concordância verbal, alguns dos fatores internos propostos são os seguintes:

a) Posição do sujeito em relação ao verbo: sujeitos pospostos favorecem a não concordância

(Chegou os menino (s));

b) Distância entre o núcleo do sintagma nominal sujeito e o verbo: quanto maior a distância entre esses dois constituintes, maior seria o cancelamento da regra de concordância verbal (Os livros, sobre a viagem dos navegantes do século XVI, já menciona o fato narrado);

c) O paralelismo no nível oracional: o menor número de marcas explícitas de plural no sujeito levaria à ausência de marcas de plural no verbo (Os peixe nada velozmente);

d) Animacidade do sujeito: sujeitos de referência animada (peixe, homem), que funcionam em geral como agentes da oração, favoreceriam a realização da marca de plural no verbo, enquanto os de natureza inanimada (barco) não a favoreceriam;

e) Paralelismo no nível discursivo: no caso de verbos em série discursiva, a ausência da marca de plural em um verbo levaria à ausência da marca de plural no verbo seguinte (os peixe pula, nada sem parar);

f) Saliência fônica (além da relação entre a tonicidade e o número de sílabas das formas singular e plural): no que se refere à diferença material fônica entre as formas singular e plural, as formas verbais mais perceptíveis, mais salientes (como, por exemplo, cantou/cantaram ou é/são), seriam mais marcadas no plural do que as menos perceptíveis, menos salientes (como come/comem)";

g) Tempo verbal e o tipo de estrutura morfossintática: testa-se, ainda, a hipótese de que os índices de concordância poderiam ser diferenciados a depender do tempo verbal e da construção sintática. (VIEIRA, 2007, p. $88)$.

O fato de haver fatores internos ao sistema da língua que podem levar os falantes a aplicar ou não uma regra foi assim uma constatação que abriu a reflexão sobre o real estatuto dos dialetos não padrões, ou seja, a heterogeneidade no uso da língua não é apenas uma questão de baixa escolaridade e não se deve apenas a características sócio-históricas das comunidades de fala. Esse conjunto de fatos e propostas foi um duro golpe ao projeto de ensino baseado no uso de manuais tradicionais.

Vejamos agora o quarto tema destacado no início, isto é, (4) mudança de perspectiva em relação à unidade linguística central no ensino, que passa a ser o texto, e não mais 
a oração ou o período. Em relação a esse tema, como é também sabido, o desenvolvimento das áreas de análise do discurso e da análise da conversação a partir da década de 60 favoreceu igualmente mudança de mentalidade em relação ao ensino de língua materna. Fez-se assim “[...] revisão das práticas pedagógicas, provocando o deslocamento do ensino centrado na gramática escolar para o ensino de práticas de linguagem, do ensino que tomava como unidade linguística a frase para o que toma o texto.” (PCN, 1997, p. 3 ).

Esse trecho que acabamos de citar é proveniente do documento do Ministério da Educação intitulado Parâmetros Curriculares Nacionais (PCN), de 1997, que traçou, como se sabe, diretrizes pedagógicas para o ensino das matérias escolares incluindo, evidentemente, a língua portuguesa. Pode-se destacar, nessa perspectiva, o trabalho organizado por Geraldi (1985), que foi determinante na elaboração dos PCN.

Nessa nova visão do ensino de língua portuguesa, defendida nesse documento, importa levar o aluno a ser um produtor e receptor competente de textos orais e escritos, pressupondo-se que, para ter um bom desempenho em escrita e leitura, não é preciso saber teoria gramatical. A hipótese da gramática internalizada ou da existência de um saber gramatical "inconsciente” por parte dos falantes, desenvolvida pela Gramática Gerativa, permitir-nos-ia legitimar essa suposição, ou seja, os alunos já "sabem gramática", pois se comunicam com perfeição, interpretando e elaborando enunciados e textos.

Essa mudança de mentalidade em relação ao ensino de língua materna encontra ainda um aliado na constatação de que, até então, não obtivemos êxito na elaboração de uma nova gramática, elaborada de acordo com uma nova perspectiva teórica, que venha a substituir os manuais tradicionais, resolvendo ou atenuando, portanto, suas dificuldades. O desestímulo em relação ao ensino de gramática parece-nos, enfim, encontrar apoio na percepção de alguns, nem sempre verbalizada às claras, de que aos alunos de hoje faltaria o interesse pela gramática e as condições de seu aprendizado, supondo-se, de maneira idealizada, que esse interesse existia outrora, o que, no nosso modo de ver, não resiste a uma análise objetiva.

Todo o material pedagógico e a prática de sala de aula passa a refletir a mudança de perspectiva no que se refere ao texto como unidade. $\mathrm{O}$ destaque é dado à produção de texto que é o sintagma que vai balizar todo o conjunto de ações necessárias à nova mentalidade. Ganha impulso o estudo dos tipos e gêneros textuais e também a distinção entre as modalidades da fala e da escrita. O aluno deverá assim se tornar um produtor/ receptor de textos orais e escritos dos vários tipos e gêneros, que se acrescentam ao gênero literário. 
E o ensino de gramática neste contexto? Torna-se coadjuvante, já que, de acordo com os PCN,

[...] é no interior da situação de produção de texto, enquanto o escritor monitora a própria escrita para assegurar sua adequação, coerência, coesão e correção, que ganham utilidade os conhecimentos sobre os aspectos gramaticais. Saber o que é substantivo, adjetivo, verbo, artigo, preposição, sujeito, predicado, etc. não significa ser capaz de construir bons textos, empregando bem esses conhecimentos. (PCN, 1997, p.89-90).

Chegamos, enfim, ao quinto tema, isto é, (5) o advento das novas tecnologias, como a internet e o celular, com consequências ainda não inteiramente descritas e compreendidas, em vários campos da ordem do humano, fazendo-nos rever concepções sobre língua e ensino.

Esse é talvez o maior desafio para o ensino, porque as consequências do que estamos vivendo em relação a essas novas tecnologias são ainda imprevisíveis e não atingem somente a escola, mas todo o conjunto de nossas práticas cognitivas e sociais. No rastro da Galáxia de Gutenberg de McLuhan (1967), o que se discute hoje são as consequências para a vida humana da formatação cognitiva gerada pelos hipertextos contemporâneos (LÉVY, 1999) e sua contribuição para o estabelecimento da mentalidade pós-moderna². $\mathrm{O}$ que vivemos com o ingresso dessas novas tecnologias tem mesmo permitido a alguns duvidar da consecução do projeto iluminista de humanização para o qual é essencial o veículo do livro. Para Sloterdijk (1999), a coexistência humana nas sociedades atuais foi retomada a partir de novas bases que são pós-literárias, pós-epistolares e, consequentemente, pós-humanistas. Isto não quer dizer, evidentemente, que a literatura e o livro vão acabar num futuro próximo, mas sim que podem se diferenciar numa subcultura sui generis.

Alguns dos resultados desse processo de inovação cognitiva, de naturezas diferentes, já se deixam perceber: pulverização das informações; superestimulação e multifo-

\footnotetext{
${ }^{2}$ A discussão sobre as consequências de novas tecnologias na nossa cognição é tão ampla quanto antiga. Observe-se, por exemplo, o trecho de Platão a seguir, em Fedro, a respeito da invenção da escrita: "Pois essa descoberta [da escrita] provocará, nas almas dos que apreenderam, o esquecimento, devido à falta de exercício da memória...”(275 a). Com a renovação recente dessa discussão, há evidentemente inúmeros pontos que exigem explicitação, a começar pela própria noção de cognição ou de cognitivo: é uma instância biológica, psicológica ou ambas? Parece-me que, devido ao nosso estágio atual de conhecimento ser muito rudimentar, essa tem sido uma noção usada para designar algo que se passa entre os dois domínios. Não há, por outro lado, segurança para afirmar isso, e não creio que haja quem o faça. Parece que quando se menciona alguma alteração cognitiva devido a uma inovação tecnológica, estaríamos lidando com mudanças de configuração neurológica ou algo do gênero. Trata-se, ainda, talvez falta de melhor, de cognição de natureza mental ou psicológica, o que não deixa, é claro, de continuar a apontar os problemas de "objetividade", caros à tradição empirista. São temas complexos e não poderemos desenvolvê-los aqui.
} 
calização, com consequente desatenção nas novas gerações, o que tem sido visto, por certas perspectivas médico-psicológicas, como uma patologia a ser tratada de forma medicamentosa; quebra dos limites entre as modalidades da fala e da escrita, no sentido de que se torna opaca essa distinção numa visão de que haveria recursos mais típicos ou exclusivos da modalidade escrita, o que, aliado a isso, introduz a consequente indistinção ou inconsciência da necessidade ou valor do papel social da normatização ou da padronização da língua; multiplicidade de suportes textuais, o que faz rever o papel do livro com instrumento por excelência de acesso à informação e do ensino. A dificuldade com a valorização da norma pode encontrar ainda justificativa em análises recentes sobre nossa época, como, por exemplo, a de Lipovetsky (2005), que aponta para um tipo de subjetividade que tenta se abster da transmissão geracional de saberes e valores, pretendendo fundar-se a si mesma.

Além da falta de espaço, problematizar ou desenvolver o que acabamos de apontar foge dos nossos objetivos neste texto. Mas para se convencer do que afirmamos, basta observar as características dos textos das mensagens trocadas hoje em dia para perceber a natureza on-line dessa escrita, o que seria, em princípio, exclusivo da fala, e como os recursos de linguagem, considerados típicos da fala, apresentam-se nos textos dessas mensagens. Os usuários, no mais das vezes, não demonstram qualquer preocupação com a adequação normativa desses textos escritos, bastando a eficiência comunicativa.

O que fazer ou o que tem sido feito com o ensino de língua materna a partir desse conjunto de fatos?

A primeira constatação inequívoca é a necessidade do abandono definitivo do ensino de língua portuguesa de acordo com os pressupostos e práticas tradicionais. Poderse-ia pensar que, pelo menos no Brasil, isto já são favas contadas. Nada disso! É suficiente observar as atividades pedagógicas que ainda são utilizadas, por exemplo, em colégios da cidade de Belo Horizonte: exercícios estruturais desvinculados com os contextos reais de uso e rechaço de variantes não padrões.

É preciso ter em mente também que embora as ideias contrárias ao ensino tradicional vicejem em nossas faculdades de letras durante as últimas décadas, não se conseguiu ainda mudar, substancialmente, a mentalidade da sociedade em geral, que teima em atribuir valor ao ensino gramatical tradicional. A resistência da sociedade e de certos ambientes educacionais é, na verdade, esperada, pois (1) mudanças de mentalidade são efetivamente demoradas, ainda mais se tratando de perspectiva de ensino que se originou há cerca de dois mil anos; (2) a nova mentalidade, provocada pelos cinco pontos supracitados, ainda não encontrou uma formatação pedagógica precisa que substitua as 
práticas tradicionais; (3) a sobrevivência da perspectiva tradicional e o apego às exceções de língua podem também indicar que sabemos, de alguma forma, que a familiaridade com os temas gramaticais são relevantes socialmente nas nossas práticas de linguagem. De fato, as pessoas são mais ou menos conscientes de que há vantagens no domínio da norma culta ou do português padrão: seu domínio capacita-nos a adequar formalmente, sobretudo, nossa escrita, e é neste registro que estão elaborados textos escritos de todas as épocas, cuja frequentação nos permite tanto adquirir quanto apreciar conhecimentos. Parece-nos fato, portanto, que, apesar de ter a consequência de servir de instrumento de dominação entre classes, a familiaridade com o português padrão possibilita aumento de poder de convencimento das pessoas e consequente ascensão social ou profissional. Ora, os manuais gramaticais são reputados como a porta de acesso a esse conhecimento.

É amplamente aceito, por outro lado, que conhecer a nomenclatura e classificações da Gramática Tradicional tem um papel irrelevante na elaboração de textos do ponto de vista da textualidade. De nada adianta, por exemplo, memorizarmos que "hiper-" é um prefixo de origem grega e "super-“ é de origem latina na hora de redigir um bom texto, coeso e coerente. Isso depende, seguramente, de outras habilidades cognitivas e também de coisas como: volume de informações, ter o que dizer e, sobretudo, de tempo e trabalho. Estamos de acordo em dizer, então, que saber escrever um texto não é igual a saber gramática no sentido tradicional; ou, em outras palavras, conhecer exceções da língua não garante bons textos orais e escritos.

Contudo, e apesar da valorização dos dialetos não padrões, parece-nos que é quase consensual que o objetivo da escola continua a ser ensinar o português do Brasil padrão, ou, pelo menos, como diz Possenti (1999, p.17), "criar condições para que ele seja aprendido". Pensar o contrário toma por base dois pressupostos equivocados: (1) a questão da imposição entre classes: ora, os oprimidos, se querem se tornar cidadãos de direito, só têm a ganhar com o contato ou domínio dos registros cultos da língua; (2) as supostas dificuldades cognitivas ou culturais de apreensão de outros registros da língua por certos segmentos da população também não resiste a uma análise objetiva, tendo em vista nossa habilidade natural de aquisição da linguagem.

O que pode ser mudado, então, já que mantemos a necessidade de viabilizar a acessibilidade aos registros cultos da língua, é a postura e o material pedagógico que a sustente, ou seja, não se trata de excluir variantes não padrões, mas, a partir dessas variantes, levar o aluno a refletir sobre a adequação das formas da língua de acordo com o contexto, o qual inclui quem fala e para quem fala, de forma a torná-lo "poliglota" no interior de sua língua materna. 
Devemos, assim, em outras palavras, continuar o trabalho paciente de revisão do conceito de erro no uso da língua: com a inclusão do maior número possível de variantes, o que enriquece o saber linguístico dos aprendizes, é preciso insistir na ideia de adequação do uso da língua de acordo com os ambientes de uso. Aliado a esse trabalho, é necessário aprofundar, como tem sido proposto por muitos, a reflexão acerca das convergências/divergências entre as modalidades da fala e da escrita.

É preciso concordar, além disso, com a proposta de que o objetivo central do ensino de língua materna é tornar os aprendizes leitores/produtores eficientes de textos orais e escritos. Toda a ênfase deve ser dada, portanto, como, aliás, já tem sido feito, à prática textual que toma os tipos e os gêneros como objeto de reflexão.

E o ensino de gramática diante desse estado de fatos? Dentre as posições extremadas de abandono do ensino de gramática e da insistência do seu ensino de maneira enfática, defendemos uma posição intermediária, isto é, cabe ainda, mas de maneira renovada, ensinar gramática, porém com um papel coadjuvante numa perspectiva de ensino que tem como objetivo central levar os aprendizes a ser tornarem produtores/receptores de textos orais e escritos de tipos e gêneros diversos.

No nosso modo de ver, tomar aspectos estruturais, quer seja de natureza morfossintática ou semântica, como objeto de reflexão tem uma função cognitiva decisiva, favorecendo a expressão dos conteúdos de forma coesa e coerente e também a padronização dos textos que produzimos. A reflexão sobre os aspectos estruturais deve ser implementada pela apreensão de nomenclatura gramatical que é o instrumento com o qual avançamos nesse processo.

Vejamos um exemplo simples: quando ocorre posposição do sujeito, a concordância verbal deve realizar-se como aparece em (2a) a seguir e não como em (2b), como ocorre, com muita frequência, em registros orais do português do Brasil:

(2) a. Saíram da sala os convidados que te chatearam.

b. Saiu da sala os convidados que te chatearam.

Já que estamos de acordo em dizer que faz parte do aprendizado da língua portuguesa levar o aluno a reproduzir, sobretudo em seus textos escritos, estruturas como (2a), em acréscimo à estrutura ( $2 \mathrm{~b})$, já disponível, pensamos que ter explicitadas noções como sujeito, verbo e concordância favorece a conscientização dessas estruturas, ou seja, o conhecimento de noções metalinguísticas como estas facilita o emprego da concordância 
de acordo com a padronização que se quer estabelecer, o que, é claro, não vai garantir um bom texto no que concerne à textualidade, mas pode contribuir para assegurar sua adequação do ponto de vista da normalização.

Nossa visão dos fatos não é incompatível com a perspectiva de ensino-aprendizagem de língua portuguesa que elege o texto como sua unidade. $\mathrm{O}$ documento Parâmetros Curriculares Nacionais, supracitado, por exemplo, que incorpora a perspectiva do texto, não deixa de reconhecer que há ainda proveito, na prática pedagógica, da reflexão gramatical. É o que se vê, por exemplo, no seguinte trecho:

O modo de ensinar [...] não reproduz a clássica metodologia de definição, classificação e exercitação, mas corresponde a uma prática que parte da reflexão produzida pelos alunos mediante a utilização de uma terminologia simples e se aproxima progressivamente, pela mediação do professor, do conhecimento gramatical produzido. (PCN, 1997, p. 29).

Prevê-se, além disso, neste documento, a inclusão, contextualizados nas práticas textuais e de comparação dialetal, de conteúdos gramaticais como os seguintes:

[...] sistema pronominal [...]: preenchimento da posição do sujeito, extensão do emprego dos pronomes tônicos na posição de objeto, desaparecimento dos clíticos, emprego dos reflexivos, [...] sistema dos tempos verbais (redução do paradigma no vernáculo) e emprego dos tempos verbais (predominância das formas compostas no futuro e no mais que perfeito, emprego do imperfeito pelo 'condicional', predominância do modo indicativo, etc.). (PCN, 1997, p. 61).

Como se vê, considera-se que não somente não há antagonismo como há proveito em tornar explícitos fatos de gramática, mesmo quando o objetivo precípuo do ensino de língua materna é desenvolver as habilidades de leitura e escrita dos alunos.

Nossa opinião é também compatível com as diretrizes contidas no documento do Ministério de Educação e Cultura, nomeado "PCN+. Linguagens, Códigos e suas Tecnologias”, de 2009.

Nesse documento, a ênfase é conceber a língua como o recurso cognitivo que viabiliza a comunicação. Contudo, prevê-se a inclusão do conceito de gramática sobre o qual se encontram as seguintes afirmações:

A língua portuguesa [...] pode ser descrita por meio de um vocabulário técnico que abarca fatos linguísticos de ordem morfológica (as noções de radical, sufixo, prefixo, por exemplo), ou sintática (a colocação pronominal $[\ldots])(\mathrm{PCN}+, 2009, \mathrm{p} .66)$. 
Essas diretrizes do MEC repercutem, e não poderia ser diferente, os temas centrais da discussão acerca do ensino de língua materna das últimas décadas. Destaco que dominar a norma culta continua sendo visto como um "eixo cognitivo" da área de linguagens e também o fato de ser prevista a exposição, e eventual conscientização, por parte dos alunos, aos recursos de gramática, descritos por metalinguagem a ser determinada.

Há lugar, portanto, para uma gramática instrumental que nos permita, a partir da gramática interna dos falantes, explicitar fenômenos da língua de maneira a ser o veículo de acesso ao português padrão. Um manual como este será fonte de consulta quando, nas práticas textuais, for necessário tomar como referência fatos do português padrão, que será considerado, portanto, como objeto de reflexão na escola.

Porém, como definir a estrutura e os conteúdos de um manual com esse perfil tendo em vista o que apontamos com os temas (1) e (2) destacados no início, ou seja, como lidar com o que chamamos de crítica interna e externa à teoria tradicional? Além disso, não podemos ignorar o advento das novas tecnologias e suas consequências, como discorremos a partir do tema (5) supracitado.

O nosso manual, já mencionado, que passo a apresentar na seção seguinte, é um esforço, já materializado, de elaboração de material didático, ou paradidático, levando-se em conta o que expomos até aqui.

\section{Gramática inteligente do português do Brasil}

No título do nosso livro, chama a atenção, de início, o qualificativo "inteligente", que restringe o termo "gramática", o qual não implica, evidentemente, o qualificativo oposto às demais gramáticas.

Para explicar a razão dessa escolha, precisamos, em primeiro lugar, retomar a constatação de que aos manuais tradicionais pode ser atribuído algum caráter enciclopédico na medida em que se encontram, além dos conteúdos relativos aos aspectos sonoros, morfológicos, semânticos e sintáticos da língua, informações acerca de grafia correta, de dialetologia, da evolução histórica da língua, de versificação, etc. Foi necessário assim realizar uma triagem de conteúdos, levando-se em conta, como critério, a relevância do tema na aquisição do português padrão, cujo emprego em textos, como já dito, é o que se almeja dos alunos.

Levando-se em conta que o conhecimento da metalinguagem gramatical deve ser desenvolvido, preferencialmente, no ensino médio, ou a partir do nono ano do fundamental, optamos por focar na apresentação da morfossintaxe da língua portuguesa do 
Brasil, descrita, de forma destacada, por meio dos critérios semântico e formal. Disso decorre, como já se verifica, que as atividades de aquisição e de treinamento ortográfico, incluindo noções como as de sílaba, de acentuação, etc., se desenvolvam ao longo das séries do ensino fundamental.

Consideramos, em segundo lugar, que outra das grandes dificuldades dos manuais tradicionais, do ponto de vista didático, é que nem sempre fica claro para quem os consulta quando se está a descrever aspectos da língua que ocorrem sempre, tratáveis através de regras, e quando se está a estabelecer exceções a essas regras. As exceções constituem boa parte dos conteúdos desses manuais e, apresentadas de forma conjunta com os fenômenos regulares de maior extensão, produzem um efeito pernicioso que é favorecer a “decoreba”, isto é, a memorização de informações, acumuladas sem reflexão. Em outras palavras, a própria apresentação dos conteúdos pelos manuais tradicionais impede sua fixação, porque sabemos que quem decora algo termina por esquecê-lo.

A escolha feita a partir dessa constatação foi a de dar destaque àquelas propriedades gramaticais que são mais amplas e regulares, as quais permitem um tratamento sistemático por meio de reflexão. É esse enfim o significado principal do termo "inteligente" no nosso título, ou seja, trata-se de privilegiar as propriedades da língua que permitam uma abordagem reflexiva, de forma a reduzir o papel da acumulação de informações por meio de memorização. Como se vê, apoia essa visão dos fatos a hipótese de gramática mental ou internalizada inerente a todos os falantes.

A abordagem reflexiva que acabamos de definir permite-nos impulsionar a autonomia do leitor, ou do estudante, na medida em que pretende torná-lo agente de reflexão que investiga a ordem interna e as propriedades racionais de sua língua e de suas práticas de linguagem, prescindindo assim da tutela de "autoridades em gramática", que se constituem a partir da acumulação enciclopédica de idiossincrasias da língua, numa versão gramatical de beletrismo. É desse horizonte, aliás, que detectamos resistências em inovar a descrição gramatical para um público mais amplo. Colabora ainda com a definição da nossa abordagem, e agora chegamos a um significado adicional do termo "inteligente", outra característica do livro que é a indicação, ao longo do texto, em boxes verticais à direita, de páginas nas quais podem ser acessadas informações adicionais sobre o tema que está, naquele ponto, sendo tratado. O leitor tem a possibilidade, assim, de transitar pelo livro na busca de detalhamento de determinado tema. Essa formatação visa a reproduzir, embora ainda não se tenha conseguido realizá-la de forma completa e para todos os temas, a estrutura de um hipertexto contemporâneo, o que permite uma leitura mais 
transversal do livro, aperfeiçoando a proposta de conferir mais autonomia ao leitor.

Esclarecido o significado do nosso título, vejamos quais são os capítulos da nossa gramática:

(1) O Português e suas Variações

(2) O Texto e a Argumentação

(3) As Classes e o Significado das Palavras e das Orações

(4) A Concordância entre as Palavras

(5) As Funções e os Papéis Temáticos dos Sintagmas

(6) Os Lugares dos Sintagmas na Oração.

Antes de comentar de que conteúdo se trata em cada um deles, é necessário discorrer sobre a definição do quadro teórico utilizado, que, como se verá a seguir, não é homogêneo. Avaliamos que não valeria a pena não levar em consideração entidades teóricas da tradição gramatical, como, por exemplo, as previstas pelas noções de classe e função, além de sua nomenclatura para designá-las. Uma razão adicional que justifica essa escolha é que o texto da nossa gramática não poderia ser radicalmente "outro", a ponto de o leitor não encontrar nenhuma familiaridade ou reconhecimento das noções apresentadas, ou, em outras palavras, não valeria a pena, apesar das deficiências da descrição tradicional, abrir mão, inteiramente, de pressupostos de análise gramatical que fazem parte do nosso patrimônio de conhecimento. Tratou-se, antes, de abordá-la com um olhar renovado.

Adotamos, portanto, boa parte do aparato descritivo da Gramática Tradicional, tendo a preocupação de (1) usar de maneira consciente critérios de análise formal e semântico; (2) distinguir, como apontado, regras de exceções ou, em outros termos, regras principais e regras secundárias, já que também as chamadas exceções permitem a formulação de generalizações; (3) racionalizar a nomenclatura tradicional, condensando noções cuja diferenciação não são julgadas relevantes em relação aos objetivos do nosso manual.

Além disso, foi-nos necessário levar em conta também certas concepções oriundas da linguística contemporânea, como por exemplo, as noções de (1) sintagma, que, como se sabe, é o constituinte que desempenha as funções de sujeito, objeto, etc., e é exigida para a definição da oração; (2) papéis temáticos, que nos permite precisar a interpretação dos constituintes que desempenham as funções que acabamos de mencionar; e (3) a de categoria vazia, oriunda da Gramática Gerativa, que é pertinente na descrição do chamado sujeito elíptico e na definição de oração. Foi preciso retomar igualmente uma noção tradicional que é pouco explorada nos manuais tradicionais. Trata-se da distinção 
entre (4) categorias lexicais e funcionais, que foi importante na definição da listagem de categorias a serem consideradas e na definição formal da oração.

Passamos a comentar, na sequência, em linhas gerais, o que contém cada capítulo do livro.

Como se percebeu, o primeiro capítulo versa sobre a variação linguística, tema obrigatório, como deixamos entender na seção anterior. Desse tema, extraímos uma dicotomia fundamental que perpassa todo o livro, a saber, as diferenças e as correspondências entre as modalidades da fala e da escrita. Abordá-la nos permitiu associá-la com os registros informal e formal da língua e explorar, ao longo do texto, como metodologia, a comparação entre os recursos para se dizer algo num registro mais informal, mais típico da fala, e os recursos para se dizê-lo num registro mais formal, mais típico ou mais esperado na escrita. Trata-se, bem entendido, do mecanismo da retextualização, desenvolvido por Marcushi (2001), convertido numa ferramenta pedagógica. Vê-se assim, com clareza, a função de levarmos em consideração e reproduzir ortograficamente os usos da língua classificados como "errados". Ora, é na comparação desses usos com os usos considerados "corretos" que se pode aumentar nossa consciência da forma dos recursos do português padrão.

O segundo capítulo localiza a oração, objeto da descrição gramatical, no ambiente do texto do qual faz parte. Não se trata de uma "gramática do texto" e sim de mostrar ao leitor que, embora, para fins de descrição, possamos destacar e nomear as partes que compõem uma oração, esta estabelece vínculos de significado no texto que dependem, fundamentalmente, da intencionalidade do falante, o que o faz elaborar figuras argumentativas para obter o que se quer, num arcabouço formal que gera tipos e gêneros textuais distintos. A condução da discussão leva-nos também a apontar os suportes textuais contemporâneos - a tela do celular ou do computador - como espaços legítimos de escrita e de transmissão de informações, o que também foi usado com o objetivo de aumentar a consciência do leitor das diferenças entre os recursos formais e informais da língua.

A observação de propriedades semânticas é fundamental para a descrição de classes de palavras desenvolvida no capítulo 3, que propõe a categorização de um item ou de uma palavra de acordo com sua natureza lexical ou funcional. Neste capítulo ainda é dado destaque à distinção de tipos de eventos e de classes semânticas de verbos, que serão decisivos na análise da atribuição de papéis temáticos proposta no capítulo 5 , no qual se estuda, fundamentalmente, como as propriedades do significado determinam as dependências sintáticas na oração. No capítulo 5, distingue-se, adicionalmente, os tipos de 
sujeito e de objeto de acordo com a interpretação dos sintagmas que desempenham essas funções e com a possibilidade de serem realizados foneticamente, o que fomenta a distinção entre sujeitos e objetos pronunciados ou não pronunciados. Por fim, é desenvolvida, nesse capítulo, a proposta de que um sujeito não pronunciado pode ocupar a "casa" ou a posição do sujeito nas chamadas, pela tradição, orações sem sujeito.

No capítulo 4, realiza-se a descrição, com base em critério formal, do fenômeno da concordância verbal e nominal, com atenção à realização da concordância de maneiras distintas de acordo com o registro mais informal, característico da fala, e com o registro mais formal, esperado na escrita. No capítulo 6, também com base em critério formal, estuda-se a colocação dos sintagmas e os deslocamentos que podem sofrer, tendo como efeito a alteração da ordem canônica. Compõem ainda o último capítulo a distinção entre subordinação e coordenação e a transformação de regência dos verbos.

Por fim, apresentamos algumas palavras acerca dos exercícios propostos no nosso manual. Estamos de acordo com a ideia de que os exercícios tradicionais, como os de substituição, desvinculados do uso real de língua, têm eficácia limitada. São elaborados, assim, exercícios, em sua maior parte, com base em textos escritos ou em transcrições de fala, que visam a levar o leitor a refletir sobre noções metalinguísticas nos usos reais da língua. Como já dito, a proposta da retextualização, de Marcuschi (2001), desempenha um papel central nessas atividades de prática linguística.

\section{Considerações finais}

Concluímos nosso livro afirmando seu caráter de incompletude, ou seja, não é possível, o que se deve à natureza recursiva da gramática como uma instância mental, descrever todos os recursos que podem fazer parte do tesouro da língua portuguesa do Brasil, o que deve funcionar como um convite para que o próprio leitor tome a língua como objeto de reflexão e análise.

\section{Referências}

BASTOS, L. K.; MATTOS, M. A. de. A Produção Escrita e a Gramática. São Paulo: Editora Martins Fontes, 1986.

CASTILHO, A. Variação Linguística, Norma Culta e Ensino de Língua Materna. São Paulo: Secretaria do Estado da Educação, 1978.

. Português Falado e Ensino da Gramática. Letras de Hoje, Porto Alegre, v. 25, n.

1, p. 106-136, jan./jun. 1990.

CUNHA, C. Gramática do Português Contemporâneo. Padrão: Rio de Janeiro, 1980. 
FREGE, G. Lógica e Filosofia da Linguagem. São Paulo: Edusp, 2009.

GARCIA, O. Comunicação em Prosa Moderna. Rio de Janeiro: Fundação Getúlio Vargas, 1973.

GERALDI, J. W. (Org.). O texto na sala de aula: leitura e produção. 2. ed. Cascavel: ASSOESTE, 1985.

HAUY, A. Da Necessidade de uma Gramática-padrão da Língua Portuguesa. São Paulo: Editora Ática, 1983.

ILARI, R. A Linguística e o Ensino da Língua Portuguesa. Martins Fontes: São Paulo, 1985.

LEMLE, M.; NARO, A. J. Competências Básicas do Português. Rio de Janeiro: Fundação Movimento Brasileiro de Alfabetização, 1977.

LEVY, P. As Tecnologias da Inteligência: o futuro do pensamento na era da informática. Tradução de Carlos Irineu da Costa. Rio de Janeiro: Editora 34, 1999.

LIPOVETSKY, G. A Era do Vazio. Tradução de Therezinha Monteiro Deutsch. Barueri: Manole, 2005.

LUFT, C. P. Moderna Gramática Brasileira. Porto Alegre: Globo, 1979.

MARCUSCHI, L. A. Da Fala para a Escrita: atividades de retextualização. São Paulo: Cortez, 2001.

MCLUHAN, M. A Galáxia de Gutenberg. Companhia Editora Nacional: São Paulo, 1977. MINISTÉRIO DA EDUCAÇÃO E CULTURA. PCN+. Linguagens, Códigos e suas Tecnologias, 2009. Disponível em: www.inep.gov.br. Acesso em: 25 maio 2010.

MINISTÉRIO DA EDUCAÇÃO E CULTURA. Parâmetros Curriculares Nacionais. Terceiro e Quarto Ciclos do Ensino Fundamental. Língua Portuguesa. Brasília, 1997.

NASCENTES, A. Método Prático de Análise Sintática. Francisco Alves: Rio de Janeiro, 1959.

OLIVEIRA, C. de. Análise Sintática. Luzir: São Paulo, 1960.

PERINI, M. Para uma Nova Gramática do Português. São Paulo: Editora Ática, 1985.

. Gramática Descritiva do Português. São Paulo: Editora Ática, 1993.

PLATÃO. Fedro ou Da Beleza. Lisboa: Guimarães Editores, 2000.

PLATÃO, F.; FIORIN, J. L. Para Entender o Texto: Leitura e Redação. São Paulo: Editora Ática, 1992.

ROCHA LIMA, C. H. Gramática Normativa da Língua Portuguesa. José Olympio: Rio de Janeiro, 1979.

SLOTERDIJK, P. Regras para o Parque Humano: uma resposta à carta de Heidegger sobre o humanismo. Tradução de José Óscar de Almeida Marques. Estação Liberdade: São Paulo, 2000. 
STARLING, M. H. Interferência da Lingua Oral no Processo de Estruturação da Escrita Escolar, 1990, 185 p. Dissertação (Mestrado em Letras, área: linguística) - Universidade Federal de Minas Gerais (UFMG), Belo Horizonte, 1990.

VIEIRA, S. R. Concordância Verbal. In: VIEIRA, S. R.; BRANDÃO, S. F. (Org.). Ensino de Gramática: descrição e uso. Contexto: São Paulo, 2007.

VITRAL, L. Por que ainda estudar gramática na escola. Revista de Estudos da Linguagem, v.10, p. 63-81, jul./dez. 2002.

. Gramática Inteligente do Português do Brasil. São Paulo: Contexto, 2017.

Data de submissão: 09/08/2017

Data de aceite: 20/09/2017 